Poster presentation

Open Access

\title{
Structure-function relationships of the HIV-I Tat protein
} Erwann P Loret

Address: Unité Mixte de Recherche Université de la Méditérranée/Institut National de la Santé et de la Recherche Médicale U911, Faculté de Pharmacie, 27 Bd Jean Moulin, 13385 Marseille, France

from Frontiers of Retrovirology: Complex retroviruses, retroelements and their hosts

Montpellier, France. 21-23 September 2009

Published: 24 September 2009

Retrovirology 2009, 6(Suppl 2):P5 I doi:I0.II86/I742-4690-6-S2-P5 I

This abstract is available from: http://www.retrovirology.com/content/6/S2/P5 I

(C) 2009 Loret; licensee BioMed Central Ltd.

HIV-1 Tat variant are short proteins with variable size and sequences regarding the HIV-1 subtypes. However a similar folding is observed among Tat variants with a core region containing the highly conserved Trp 11 . Tat was first described as an activator of HIV genes. However, Tat is the only HIV protein to be secreted from HIV infected cells and has also the capacity to cross cell membranes. Extra cellular Tat can induce apoptosis to immune cells and this is certainly essential for the virus in allowing the survival of HIV infected cells producing viral particles. This review describes the structure-function relationships of Tat that should help to develop efficient therapeutical approaches, particularly a vaccine. A vaccine targeting Tat could restore the cellular immune response and the elimination of HIV infected cells leading to a curative treatment against AIDS. However, seropositive patients are unable to develop an efficient humoral response against Tat and therefore the development of a Tat vaccine have to take in account this phenomenon with a protein that can tolerate up to $40 \%$ mutations without loss of activity but changes in its immunogenicity. 